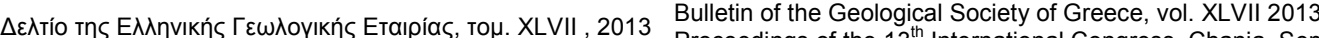
$\triangle \varepsilon \lambda$ Proceedings of the $13^{\text {th }}$ International Congress, Chania, Sept.

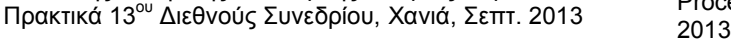

\title{
THE MESOHELLENIC TROUGH AND THE THRACE BASIN. TWO TERTIARY MOLASSIC BASINS IN HELLENIDES: DO THEY REALLY CORRELATE?
}

\author{
Kilias Ad. ${ }^{1}$, Vamvaka A. ${ }^{1}$, Falalakis G. ${ }^{1}$, Sfeikos A. ${ }^{1}$, Papadimitriou E. ${ }^{2}$, \\ Gkarlaouni Ch. ${ }^{2}$ and Karakostas B. ${ }^{2}$ \\ ${ }^{1}$ Aristotle University of Thessaloniki, Department of Geology,kilias@geo.auth.gr \\ ${ }^{2}$ Aristotle University of Thessaloniki, Department of Geophysics
}

\begin{abstract}
Based on lithostratigraphic and structural data, as well as geological mapping, the mollasic Thrace Basin (ThB) in NE Greece (including the Paleogene deposits of the Axios Basin) was compared with the Mesohellenic Trough (MHT) in NW Greece. Both basins are characterized by a thick sedimentary sequence of molassic-type strata (3-5km thickness) of Tertiary age, overlain unconformably by MiocenePliocene and Quaternary deposits. Molassic sedimentation started almost simultaneously in both areas during the Mid-Upper Eocene but it finished in different time, in the Mid-Upper Miocene for the MHT and the Upper Oligocene for the ThB, respectively. Sedimentation in ThB was also linked with an important calc-alkaline and locally shoshonitic magmatism of Eocene-Oligocene age. We interpreted the MHT as a polyhistory strike-slip and piggy-back basin, above westward-emplacing ophiolites and Pelagonian units on the cold Hellenic accretionary prism. In contrast to MHT, the ThB evolved as a Paleogene supra-detachment basin above the strongly extended during the Eocene-Oligocene Hellenic Hinterland. The syn-depositional magmatic products, linked possibly with subduction processes in Pindos or Axios ocean(s). In any case, MHT and ThB are related to inferred oblique convergence of the Apulia plate and the internal Hellenic units.
\end{abstract}

Keywords: Basin analysis, molasse, Hellenides, extension, compression.

\section{Пєрí $\eta \psi \eta$}

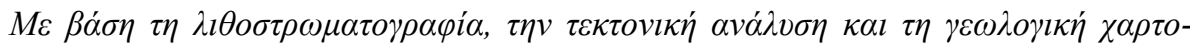

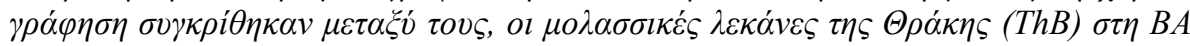

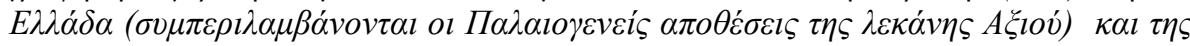

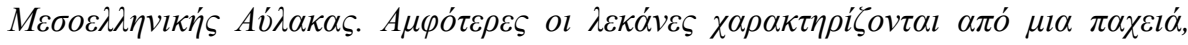

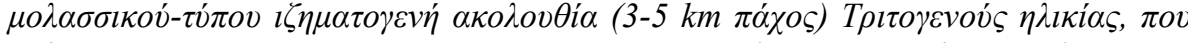

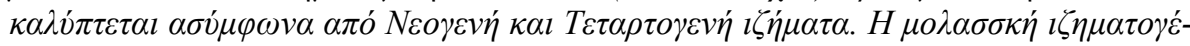

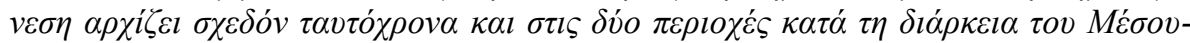

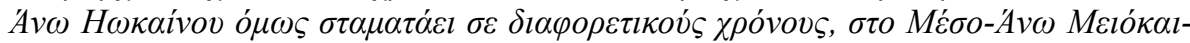

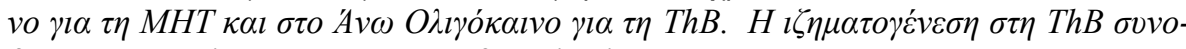

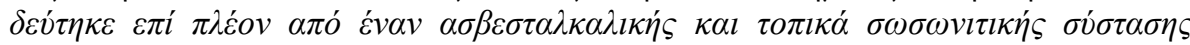

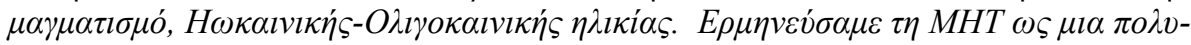

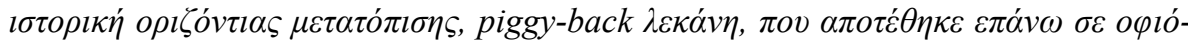

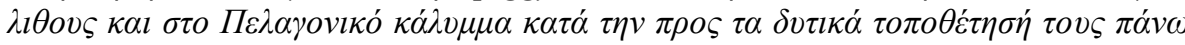

XLVII, No $2-551$ 


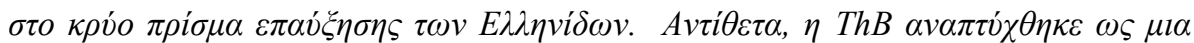

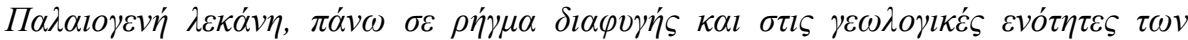

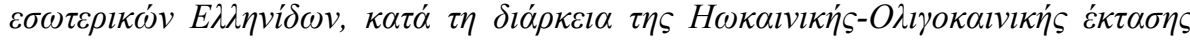

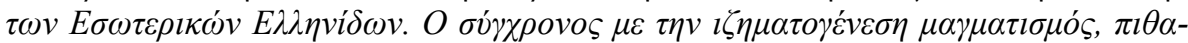

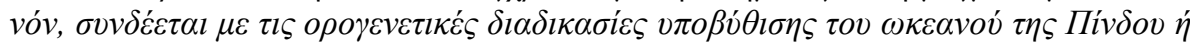

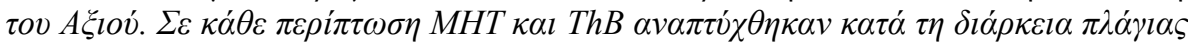

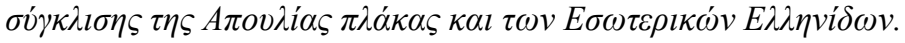

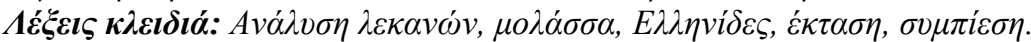

\section{Introduction}

The Mesohellenic Trough (MHT) in NW Greece (Brunn, 1956; Doutsos et al., 1994; Zelilidis et al., 2002; Ferrière et al., 2004; Vamvaka et al., 2006, 2010) and the Thrace Basin (ThB) in NE Greece (Christodoulou, 1958; Lescuyer et al., 2003; Kilias et al., 2006, 2012; Maravelis et al., 2007; Meihold \& BonDagher-Fadel, 2010) including its possible continuation into the Axios Basin (AxB; Dumurtzanov et al., 2005), constitute two large late to synorogenic Tertiary molassic-type basins in the Hellenides (Figure 1). Younger, Neogene-Quaternary, unconformably overlying clastic sediments are not considered. Although these basins dominate with their size in the Hellenic orogen and the surrounding region (Figure 1; Albania, Bulgaria, Turkey; References herein-see above), and while a lot of works with different approaches were published for each basin, there still doesn't exist any comparison between the two basins until today, concerning their structural and stratigraphic evolution during the Alpine orogeny in the Hellenides. Furthermore, it is known the great industrial potential of both basins due to gold-mineralizations and their possible hydrocarbon supplies (Lescuyer et al., 2003; Kontopoulos et al., 1999; Zelilides et al., 2002).

This work is the first attempt to compare the evolutionary history of the two basins, as well as their paleogeographic and geotectonic setting in the Hellenic orogen, at least during their molassic-type sedimentation period, taking into account our previous studies on both basins and any different published work for each basin's development. Although, both basins have a similar lithostratigraphic age, evolved mainly during the Paleogene, they differ in their structural evolution and geotectonic position in the frame of the Hellenic orogen and its evolutionary stages.

\section{Geological Setting and Structural Features}

The Mesohellenic Trough (MHT): The Mesohellenic Trough (MHT) is located in north-western Greece and Albania, and has a length of more than $200 \mathrm{~km}$ and a width of 30-40km (Figure 1). The basin developed from Middle Eocene to Upper Miocene time, related to the Alpine orogenic processes, and is sited parallel to the structural fabric of the Hellenides (i.e. NNW-SSE), between the Apulian microplate (External Hellenides, non-metamorphic) and the Pelagonian block (Internal Hellenides, metamorphic).

The basin comprises five molassic-type formations (Figure 2, 3a; Brunn 1956), overlying the NeoTethyan ophiolitic rocks and the transgressive Upper Cretaceous limestones or the western Pelagonian margin. Upper Miocene to Quaternary deposits overlie unconformably the molassic-type formations, which, from bottom to top, are (Figure 3a): 1) Krania Formation of Middle-Upper Eocene age and a thickness of 1500 m (Brunn, 1956; Wilson, 1993; Zelilidis et al., 2002; Ferrière et al., 2004). 2) Eptachori Formation of Uppermost Eocene-Lower Oligocene age and a thickness of about 1000-1200m (Brunn, 1956; Zelilidis et al., 2002). 3) Pentalophos Formation of Upper Oligocene-Lower Miocene age, which attains a cumulative thickness of around $2500 \mathrm{~m}$ (Brunn, 1956; Doutsos et al., 1994; Ferrière et al., 2004; Zelilidis et al., 2002), while in the central part of the formation it is estimated to reach a maximum thickness of $4000 \mathrm{~m}$ (Zelilidis et al., 2002). 4) Tsotyli Formation of Lower-Middle Miocene age and a thickness of about 1500 m (Brunn 1956; Zelilidis et al. 2002), and 5) Ondria Formation of Middle Miocene age (Burdigalian-Langian), 
which remains only in a few places of the MHT with a thickness of about $350 \mathrm{~m}$. With the exception of the Krania Formation in the westernmost and the southeastern parts of the MHT, the other four formations were deposited parallel to one another from west to east, respectively (Figure 2), with an overall eastward migration of the depocenters and subsidence (Brunn, 1956; Zygogiannis \& Müller, 1982). Accordingly, Tsotyli formation directly rests on top of the Pelagonian microcontinent along the eastern margin of the trough. At the western edge of the basin, the strata dip towards the ENE at steep angles; dips decrease progressively away from this basin margin, whereas along the eastern margin of the basin the strata dip with a low angle towards the WSW. As a result an asymmetrical syncline is formed, controlled by structural and depositional processes (Figure 2). The MHT splits into two narrower synclines in the south separated by an uplifted structure (Theotokos-Vassiliki villages' areas; Doutsos et al., 1994). Furthermore, all formations, except the Eocene Krania Formation, become coarser towards the southern part characterized by extensive fan delta deposits (Zelilidis et al., 2002).

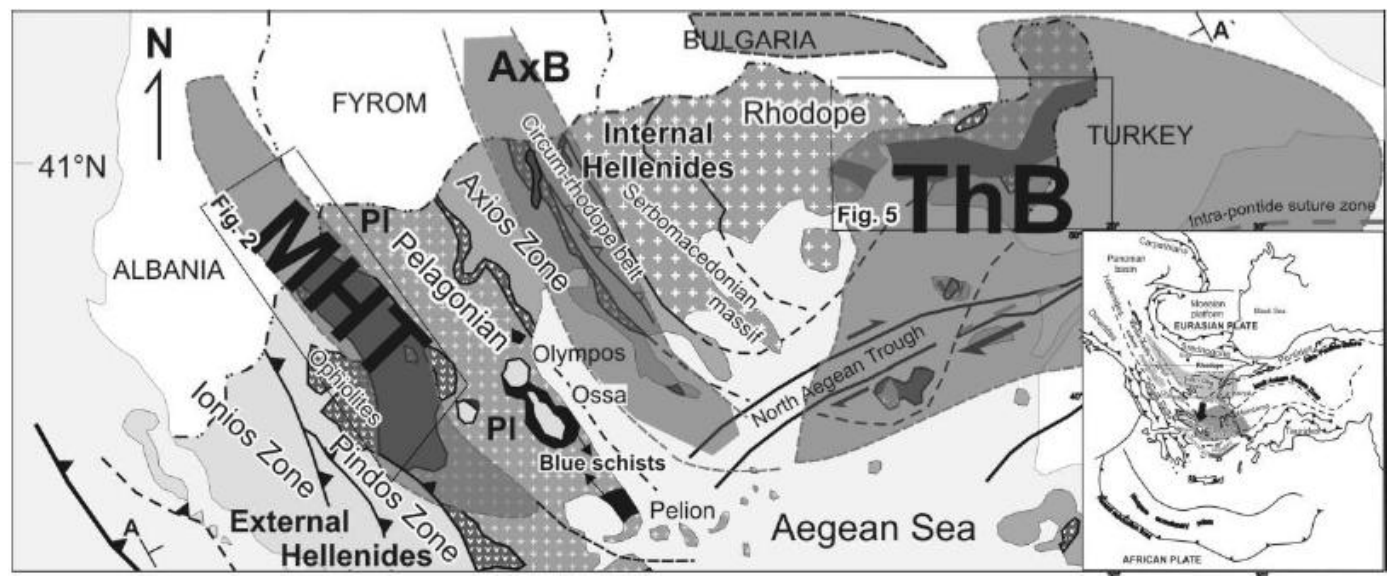

Figure 1 - Location of the Mesohellenic Trough (MHT) and the Thrace Basin (ThB) in the Hellenides and their possible paleogeographic extension in Greece and surrounding areas is shown (AxB Axios Basin; dark gray, the outcrops of the molassic strata in Northern Greece). Insert: the Hellenides as part of the Alpine orogen in the Eastern Mediterranean region; square shows the study area. The SSW migration of the Tertiary magmatic activity ih Hellenides is also indicated (from Eocene until today). A-A' cross section of Figure 6.

Numerous structural data, accrued from observations on geometry of kinematics, overprinted criteria, stratigraphic relationships and correlation between various structures, show that the basin experienced a complicated history with different tectonic episodes (T1 to T5; Figure 2, 4a; Vamvaka et al. 2006). These events took place in semi-ductile to brittle conditions from Middle Eocene to Quaternary time.

The first stage (T1) of the basin's development, during Middle-Upper Eocene, was contemporaneous with the final emplacement of Pindos ophiollites and culminated in deformation and uplift of Eocene strata. The Eocene sub-basins developed by crustal flexure and subsidence due to loading of the overthickened Hellenides accretionary prism. Basin evolution was associated with transpressional regime and strike-slip faults with reverse, towards NE component. During the ensuing followed basin closure, intense deformation and uplift at the end of Eocene, the sediments of the first sub-basins were deformed, and placed with a high angle at the western basin margin, locally concordant with the adjacent ophiolitic rocks. The second phase (T2) was dominated by strike-slip faults. Dextral strike-slip faults of NW-SE to NNW-SSE orientation controlled the subsidence and evolution of the basin from Lower to Upper Oligocene. Strike-slip faults, positive flower structures and rare compressional structures have been developed under a transpressional regime which is characterized only by a decrease in intensity in comparison to the first Eocene regime, and a small shift of the maximum principal stress axis $(\sigma 1)$ from NE-SW towards NNE- 
SSW (Figure 2,4a). The third stage (T3) was characterized by low-angle normal faulting along the eastern boundary of MHT during Lower-Middle Miocene, which increased the subsidence at that part of the trough (Figure 2,4a). T3 was associated with the syn- to late orogenic collapse and detachment of the Pelagonian nappes (Kilias et al., 1991a, b; Sfeikos et al., 1991). The evolution of the sedimentary basin ended around Middle-Upper Miocene, followed later by rapid uplift and marine regression. A compressional event occurred during the Upper Miocene times, related to reverse and strike-slip faulting, which cut the MHT formations (T4; Figure 2,4a). Finally, extensional tectonics affected the area from Upper Miocene to present-day related to high angle normal faults, some of which are great active faults (T5).

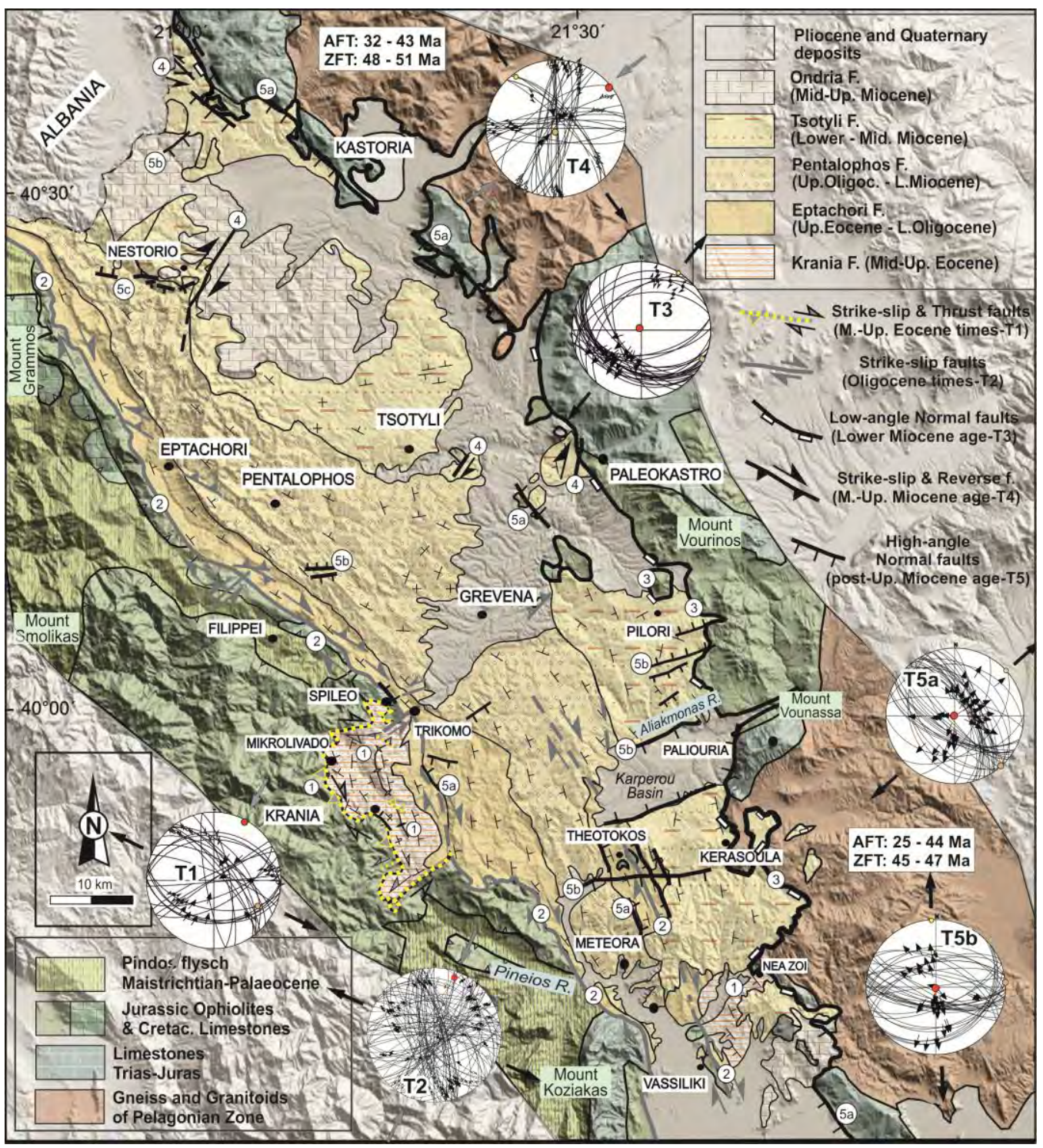

Figure 2 - Geological-structural map of the MHT (modified after Brunn 1956, Zelilidis et al., 2002, Doutsos et al., 1994, Vamvaka et al., 2006). Schmidt diagrams (equal area, lower hemisphere) show the fault planes and slip directions, as well as the calculated paleostress axes (inversion method Angellier 1979; $\sigma 1>\sigma 2>\sigma 3$ ) for each tectonic event (T1-T5). Numbers in circles correspond to the tectonic events. AFT and ZFT ages from Pelagonian basement are shown in boxes. 
Fission track (FT) analyses were also performed on the MHT sediments and their bordering Pelagonian basement rocks, towards the comprehension of the MHT development. FT data from detrital apatite from the MHT (Figure 3a; Vamvaka et al., 2010) are characterized by two main age populations (i.e. Eocene and Upper Cretaceous to Paleocene ages) and confirm the adjacent to MHT Pelagonian microcontinent as the main source of the detrital material. Eocene AFT age populations (between 50 and $30 \mathrm{Ma}$ ) in the Eocene (up to Miocene) sedimentary strata indicate a proximal position of the Pelagonian microcontinent, which shows the same or even younger AFT ages. Upper Cretaceous to Paleocene age populations (between $\sim 60$ and $\sim 100 \mathrm{Ma}$ ) point to a more distant or structurally higher (now eroded) source area. This is also concluded from the FT age pattern in the relevant units in the southern F.Y.R.O.M. (Former Yugoslavia, Republic of Macedonia), where a clear AFT age gradient from higher age in the east to lower ages in the west is documented (Most et al., 2001). From AFT age components of samples deriving from the western part of the trough, the Pelagonian microcontinent is denoted as the probable, at least partly, source area of those deposits since the beginning of Upper Oligocene. No correlation with AFT ages of the western bordering basement rocks was available due to inappropriate lithology.

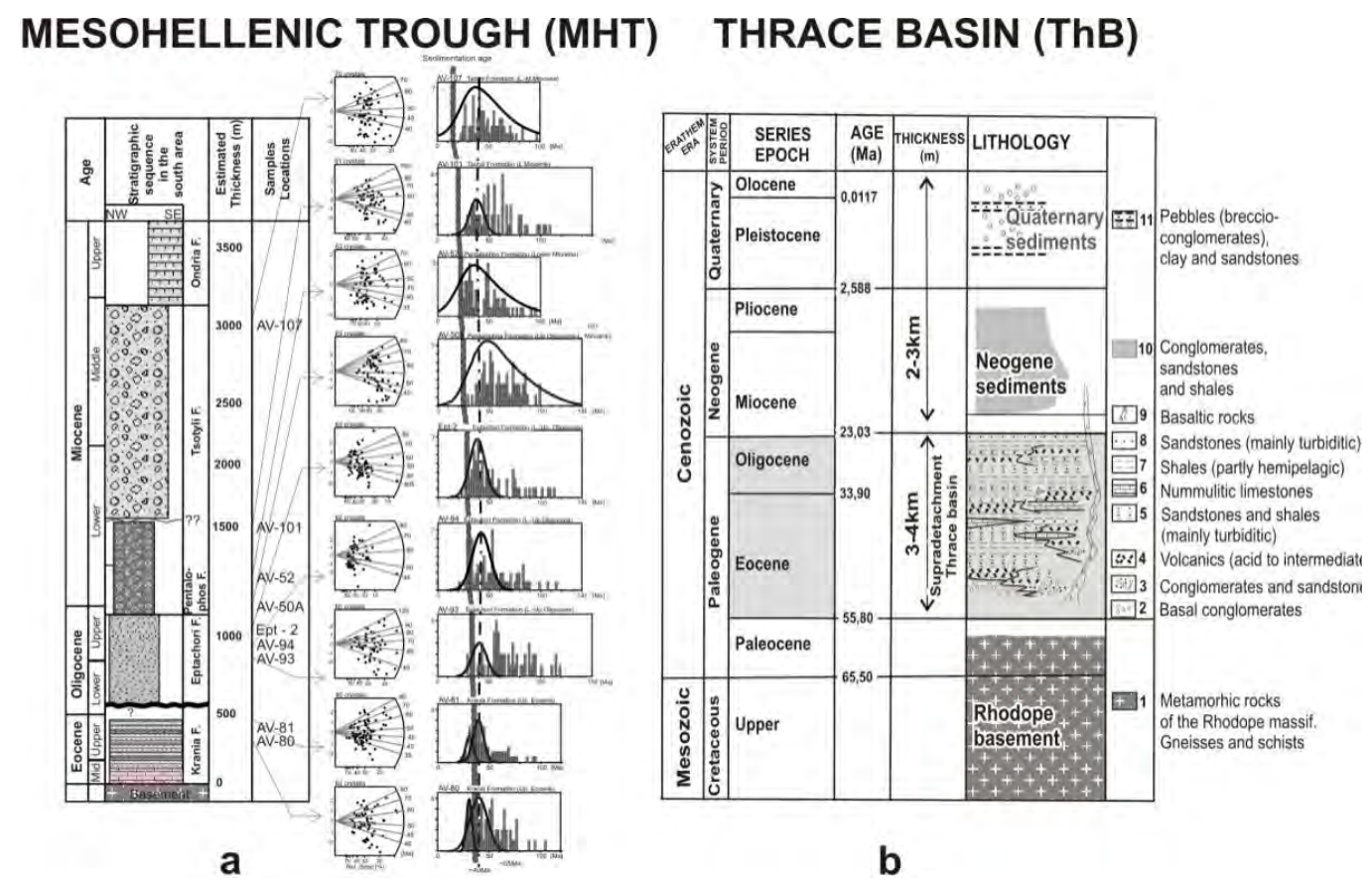

Figure 3 - Schematic lithostratigraphic columns of the MHT (a) and the Thb (b). Apatite FT data from the MHT-formations are also shown (Vamvaka et al., 2010; Kilias et al., 2012). The continuous line (a) refers to the stratigraphic age of the basin deposits.

According to the FT results, the Eocene orogenic event caused only weak thermal overprinting in the rocks of the Pelagonian microcontinent. In its eastern part, the AFT ages show only partial resetting, if any, whereas in its western part the ages were clearly reset during the Eocene event. AFT age-elevation relations, correlation of zircon and apatite FT ages from the same samples, and thermal modelling, based on AFT ages and track length distributions, were all used to reconstruct the low-temperature cooling history of the Pelagonian basement adjacent to the MHT. The results document fast cooling and exhumation in the Eocene that was possibly related to the erosion subsequent of the Eocene thrusting (Kilias et al. 1991a,b; Schermer et al. 1993), followed by slow cooling and exhumation during Oligocene and Miocene time. This scenario is confirmed by the AFT data from the detrital material in the MHT sedimentary strata, and the increasing lag times resulted for increasing stratigraphic age. The slow cooling period (between $\sim 30$ to $10 \mathrm{Ma}$ ) 
coincides with a stagnation period or crustal extension and possible reheating; this could have been responsible for the partial rejuvenation of the ages of the detrital apatites showed for the oldest (Eocene) formation of the sediment sequence of the MHT (Figure 3a).

The conclusions deduced from the FT results meet the conclusions from the structural analysis, both for the Eocene event and the subsequent change in the tectonic regime. Heating of the western Pelagonian microcontinent adjacent to the MHT, during Lower-Middle Eocene, was associated to thrusting, and directly followed by fast cooling and exhumation in Middle-Upper Eocene. The slower cooling and exhumation in the continuing during Oligocene is associated to the strikeslip faults (T2) which cause localized uplift and subsidence (in the area of MHT), while less vertical movements are produced in other places (e.g., the Pelagonian micro continent). The Miocene extensional period (T3) is also shown from thermal modelling of track length distribution, which indicates a prolonged stay in the same temperature range (or reheating) around $\sim 25$ to $10 \mathrm{Ma}$. This can be caused by crustal thinning and rise of the geothermal gradient, started already since Oligocene-Miocene time, accompanying an extensional period. In the latter thermal model, an enhanced uplift is also predicted during the last $10 \mathrm{Ma}$, which is in consistence with the filling of the basin with sediments and the uplift of the area.

Geodynamically, the MHT evolved as a piggyback basin in a foreland setting above westwardemplacing ophiolites and higher Pelagonian units (Figure 4a; Wilson, 1993, Doutsos et al., 1994, Ferrière et al., 2004; Vamvaka et al., 2006), while great importance is given to the role of strikeslip faults in the structural evolution of the MHT (Vamvaka et al., 2006, 2010). Successive stages and changing tectonic regimes recognised in MHT formation are met in strike-slip basins, while experiencing alternating periods of extension and compression. The changing structural settings and repeated episodes of rapid subsidence and uplift, variable depths along the axis of the basin, asymmetry and big length-to-width ratios (4:1), axial infill subparallel to the principal displacement zones, abrupt lateral and vertical facies variations, and of course the presence of strike-slip
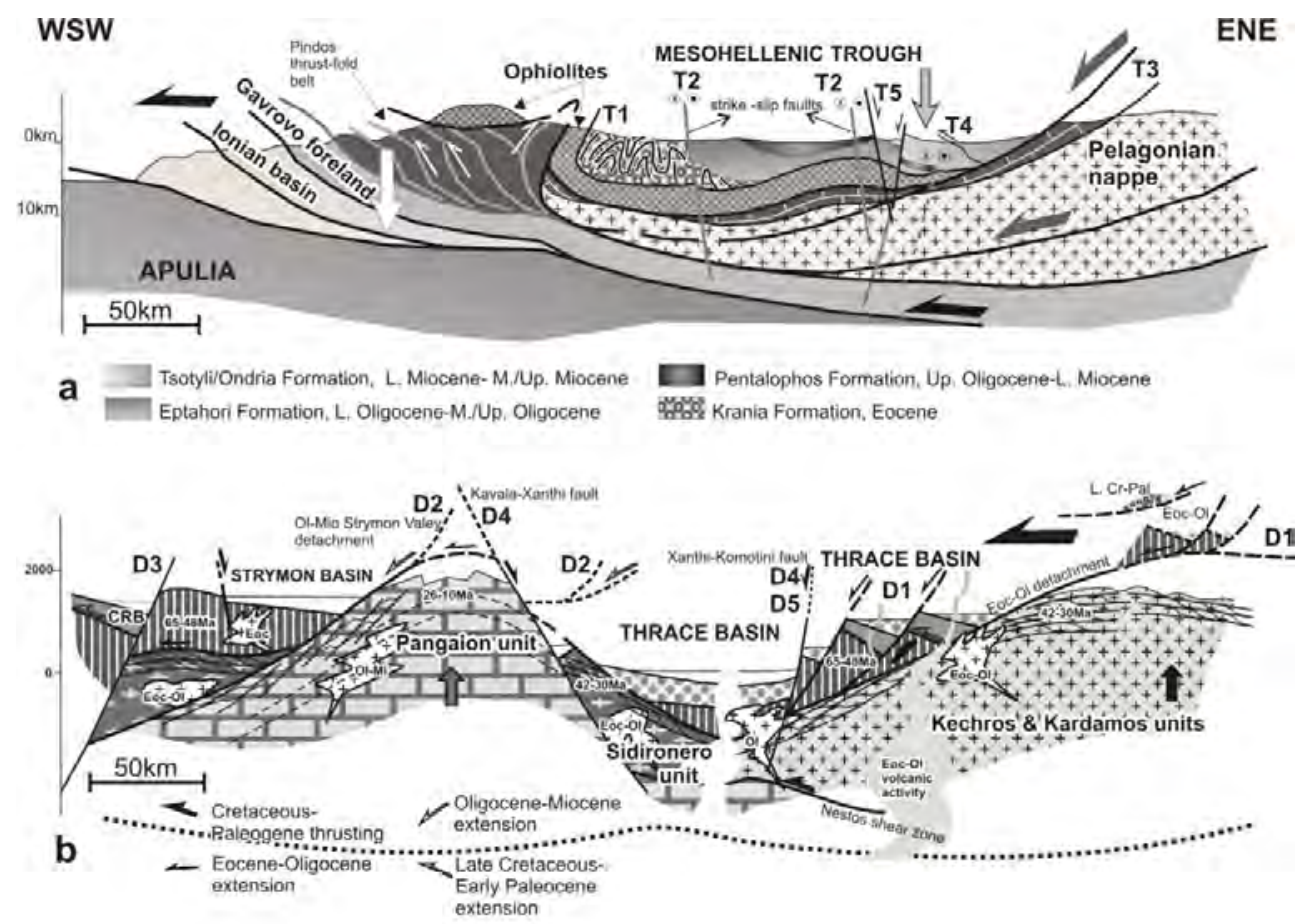

Figure 4 - Schematic cross sections through the MHT (a) and the Thb (b) showing the successive deformational stages related to the basins building (a. Vamvaka et al., 2006; b. Kilias et al., 2012). Legend as in Figures 2 and 5. 
faults as certainly observed to bound the western side of the MHT, are some indicative characteristics of the MHT, typical criteria for the recognition of long-lived strike-slip zones and related basins. As the trough developed due to different tectonic events reported earlier, it corresponds to the pattern of polyhistory strike-slip basins (classification after Busby \& Ingersoll, 1995).

In conclusion, our interpretation for the evolution of MHT suggests successive tectonic events, in response to which MHT developed, involving isostatic crustal flexure, strike-slip faults, associated with reverse dip slip component, and normal faulting (Figure 4a). This differs from previous interpretations that envisaged foreland flexure related to west-dipping backthrusting (Doutsos et al., 1994), or subsidence associated with asymmetrical flexure and normal faulting (Ferrière et al., 2004).

The Thrace Basin (ThB): The deposits of the Trace Basin in Greece (ThB) consist molassic-type sedimentary rocks of Paleogene age overlain unconformably by a thick $(1-2 \mathrm{~km})$ NeogeneQuaternary sedimentary sequence (Figure 3b, 4b, 5; Christodoulou, 1958; Kopp, 1965; Mainhold and Bon Dagher, 2010). More than $90 \%$ of the total surface of the ThB is covered by younger Neogene to Quaternary sediments and the Aegean Sea. About 10\% of the Paleogene exposed outcrops of the basin is extended in the NE Greek mainland, from the Pangaion mountainous range until the Greek -Turkey borders, and the North Aegean islands of Limnos and Samotraki (Figure $1,5)$.

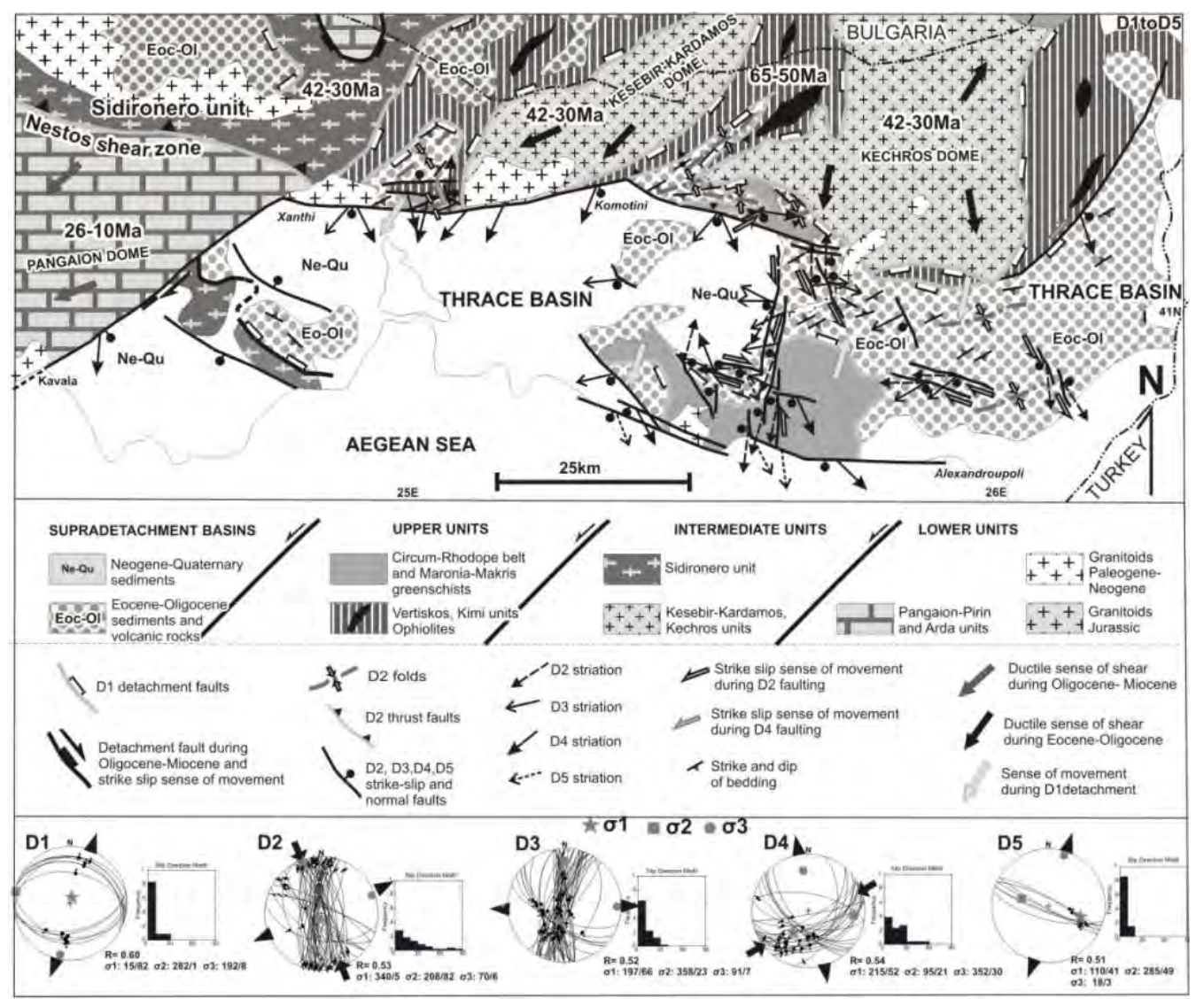

Figure 5 - Geological-structural map of the Thb and the Greek part of the Rhodope massif (modified after Kilias et al., 2012; Burg, 2012). The main structures and kinematics for each tectonic event (D1-D5) are illustrated. Fault -striae data and the deduced paleostress field $(\sigma 1>\sigma 2>\sigma 3)$ direction for each tectonic event are also shown (inverse method, Angelier, 1979; equal area, lower hemisphere). 
Some small outcrops of Paleogene sediments along the Axios Basin beneath Neogene-Quaternary sediments (Figure 1) were regarded as equivalent infilling products to the Paleogene ThB sedimentary rocks. The Paleogene molassic sediments of the $\mathrm{ThB}$, as well as their equivalent of the Axios Basin show an age from Middle-Upper Eocene to Oligocene (Christodoulou, 1958; Dragomanov et al., 1986; Roussos, 1994; Mainhold and Bon Dagher, 2010). They constitute a complicated stratigraphic sequence composed by intercalation of bedded conglomerates, breccias, conglomerates, sandstones, nummulitic limestones, turbiditic layers and shales (Figure 3b).

Sedimentation started during Lutetian- Bartonian time with initial deposition of continental sediments (mainly breccias, conglomerates and sandstones), followed during Upper EoceneOligocene by marine turbiditic type deposits and limestones. The sediments of the ThB lie in places on the basement rocks of the Rhodope massif and in other places on the low-grade metamorphic Permo-Triassic, volcanosedimentary Nea Makri unit (Figure 5; Bonev et al., 2006; Kilias et al., 2012; Burg, 2012). The total thickness of the Paleogene sedimentary sequence is estimated to 2-3 km (Christodoulou, 1958; Kopp, 1965; Burchfiel et al., 2003), although in the Turkish part of the broader Thrace Basin, where its depocenters are developed, a thickness of about $9 \mathrm{~km}$ is reported (Goeruer and Okay, 1996). Moreover, Roussos (1994) refers that also in some parts of the Greek ThB, which are covered by the Neogene-Quaternary sediments or the Aegean Sea, the sedimentary deposition can reach a thickness of ca. $9 \mathrm{~km}$.

The molassic-type sediments of both Thrace and Axios Basins, are intercalated by a lot of calcalcaline and partly shoshonitic-type, acid to intermediate volcanic products of the same age, MidUpper Eocene to Oligocene (Christofides et al., 2004; Dumurtzanov et al., 2005; Figure 3b, 4b). Magmatic activity was further related to gold-mineralization of great economical importance.

Detail structural analysis and geological mapping, as well as study of the kinematics of deformation of the sedimentary-volcanic sequence of the Thrace Basin and its boundaries with the basement rocks of the Rhodope massif and Nea Makri unit, show a complicated structural evolution of the basin. It can be recorded in five progressive tectonic events (D1 to D5) from Eocene to Quaternary time (Figure $4 \mathrm{~b}, 5$ ). Subhorizontal entension dominates during the overall deformational history (Kilias et al., 2012).

D1 is characterized by low angle normal detachment faults recognized at the tectonic boundaries of the Paleogene basin formation with the basement rocks, where no reworking took place due to younger tectonic events. D1 detachment faults strike mainly E-W to NW-SE with S-SW-ward dip direction. Some deviations of these rates are observed at different parts of the basin (Figure $4 b, 5$ ). Top to SW to SSW sense of shear dominates along the D1 fault planes but in some places an opposite top to the NE-NNW sense of movement is also recognized. D2 evolved during Oligocene-Miocene time and is related to the further opening and reconstruction of the Trace Basin. D2 is characterized by transpressional tectonics and formation of large conjugate strike-slip faults and extensional fractures, as well as thrust faults and folds with N-NW or S-SE sense of movement (Figure 5). D2-extension remains again NE-SW oriented, ca. parallel to the D1extension, while compressional component of deformation is developed parallel to the Y-axis of the strain ellipsoid. D3 is responsible for high-angle normal faults dismembering the EoceneOligocene molassic basin into Neogene grabens. Some D2 strike-slip faults are reactivated during D3 event, as it is clearly concluded by the existence on their fault planes of oblique, to the strikeslip movements, D3-striations with normal sense of movement. D3 event takes place during Miocene-Pliocene time while D3 extension continues about at the same orientation, NE-SW to ENE-WSW, with the earlier D1 and D2 events. The D4-event is related to large WNW-ESE to NE-SW normal oblique fault zones some of which are older, reactivated during D4, as it is indicated by the existence of at least two striations ' generations on their fault planes, with the younger one to be compatible with the D4 kinematics. D4 structures are also characterized by minor oblique reverse faults. Extension orientation changes slightly during D4 to NNW-SSE, associated with a subhorizontal ENE-WSW contraction (Figure 5). Some of the D4 fault zones 
remain active until present time (D5). They form large active faults reactivated during the present stress field in the area defined by the earthquake focal mechanisms and characterized by a NNESSW oriented subhorizontal extension (Figure 5).

We interpret the Paleogene ThB in NE Greece mainland as a supradetachment basin above the stretched, during the Tertiary, Rhodope massif of the Hellenic hinterland (Kilias et al., 2012). The Paleogene volcanosedimentary infilling of the Axios Basin is regarded as equivalent to the Greek Thrace Basin sedimentary sequence (Figure $4 b$ ).

\section{Discussion-Conclusions}

Molassic-type sedimentation starts in both basins, MHT and ThB including the paleogene sequence of the Axios Basin, simultaneously during Mid-Upper Eocene time (Lutetian-Bartonian) but it finishes at different time, at the Mid-Upper Miocene for the MHT and the Upper Oligocene for the Thb and its equivalent part of the Axios Basin. This Tertiary, westwards progressive delay of the sedimentary stoppage in both areas, is compatible with the W-SW-wards orogen migration of the Hellenides during the Tertiary (Kilias et al., 1999). Neogene-Quaternary sediments lie discordantly on the molassic deposits of the basins, forming the last intramontane basins of Hellenides. Furthermore, the ThB and its equivalent sequence of the Axios Basin is characterized by abundant volcanic products associated with granitoid intrusions of similar age into the Rhodope basement rocks under syn- to late orogenic extension (Kilias \& Mountrakis, 1998, Marchev et al., 2006). Nevertheless, important strike-slip movements of Oligocene-Miocene age associated with transpressional or transtensional structures are common during both basins' evolution, showing the great significance of such strike-slip movements along the Hellenides during the Tertiary. Both basins show further analogous deformational setting during the Neogene-Quaternary time with the development of local compressional structures followed again by a general extension regime. Active faults with about the same kinematics, NNE-SSW for the Thb and NNW-SSE for the MHT, dominate also in both areas.

The MHT was evolved as an intramontane piggy-back basin above the ophiolitic nappe and the higher Pelagonian units, during their westward traveling upon the cold Hellenic accretioniary prism (Figure 4a, 6). This geotectonic position, on the cold accretionary prism (Lower plate), interprets well the total lack of any magmatic activity during the basin evolution. Initial isostatic crustal flexure associated possibly with back-thrusting toward east (Mid-Upper Eocene), strikeslip faulting (Oligocene-Miocene) and finally normal detachment faulting towards west (LowerMiddle Miocene) were the main motor mechanisms related to basin evolution (Vamvaka et al., 2006, 2010). Some different interpretations for the basin evolution were proposed by Ferriere et al. (2004) or Doutsos et al. (1994), who envisaged asymmetrical flexure controlled by normal faulting or foreland depression related to backthrusting towards east, respectively. In contrast to the MHT, at least the studied part of the Greek ThB, including the Paleogene deposits of the Axios Basin, evolved as a Paleogene supradetachment basin above the strongly stretched, during the Eocene-Oligocene, Hellenic Hinterland (Figure 4b, 6; Kilias et al., 1999, Bonev et al., 2006). Exhumation of deep crustal levels took place about simultaneously with basin subsidence and migration of deformation towards W-SW, as well as with the progressive change of the tectonic conditions from ductile to brittle during the Paleogene - Neogene (Kilias et al., 1999, 2012). The origin of the Upper Eocene-Oligocene syndepositional magmatic activity could be attributed to the subduction processes evolved during the Paleogene more further to the W-SW in Pindos or Axios ocean(s). So that it is concluded that extension and basin formation in the Rhodope province took place simultaneously with contraction, nappe stacking and crustal thickening as well as HP/LT metamorphism at the more external parts of the Hellenides towards the foreland (Figure 6).

However, Marchev et al. (2005) explain the origin of the Paleogene magmatism and the simultaneous extension and crustal thinning of the Rhodope continental curst due to convective removal of the lithosphere and mantle diapirism, while Tranos (2009) and Maravelis et al. (2007) 
regard the Thrace Basin as a fore-arc basin but without clear evidence about the existence or position of a Tertiary accretionary prism associated to the basin formation.

In conclusion, according to our descriptions about the structural evolution and stratigraphic features of the MHT and ThB (including the Axios Basin), we assume that both basins constitute independent basin structures, evolved in different geotectonic positions and do not represent lateral continuation. The ThB evolved on the stretched and thinned upper plate of the Hellenic hinterland, above of a subducted slab of the lower plate during the Tertiary (Figure 6). Basin subsidence was associated with tectonic denudation and exhumation of deep crustal metamorphic rocks of the Rhodope province, as well as with abundant magmatic products. The MHT was evolved on the cold, thick crustal part of the External Hellenides, in the foreland area behind the Tertiary accretionary prism of the Hellenides and the Tertiary subduction zone (lower plate during the Tertiary orogenic processes) so that no important magmatic activity accompanied the sediments deposition during the basin evolution (Figure 6).

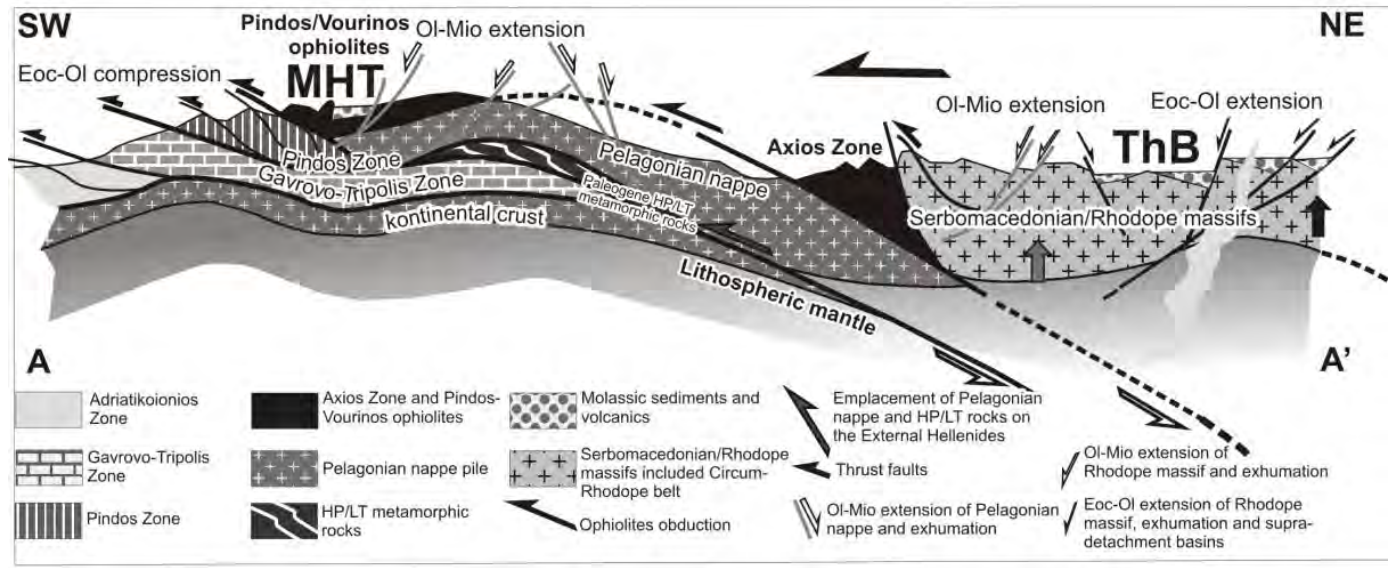

Figure 6 - Cross section through the Hellenides showing the geotectonic position of the MHT and ThB during the Tertiary orogenic processes in Hellenides. Extension acts simultaneously with compression during orogenic evolution.

In any case, MHT and ThB tectonic history seems to be related to an overall oblique plate convergence of the Apulia plate (External Hellenides) and the Internal Hellenides units during the Tertiary, as it could be inferred by the important Tertiary strike-slip motions dominated in both areas (Vamvaka et al., 2006, 2010; Tranos et al., 1999).

\section{Acknowledgments}

The research was supported by the projects, "PENED 2003" and "Pythagoras II" by GSRT, and the "Excellence Post-doc Scholarship" by RC AUTh. The authors would like to thank two anonymous referees and the editor M. Manoutsoglou for careful reviews and their insightful comments and suggestions on the manuscript.

\section{References}

Angelier J. 1979. Determination of the mean principal direction of stresses for a given fault population, Tectonophysics, 56, T17-T26.

Bonev N., Burg J.-P. and Ivanov Z. 2006. Mesozoic-Tertiary structural evolution of an extensional gneiss dome - The Kesebir-Kardamos dome, eastern Rhodope (Bulgaria-Greece), Intern. J. Earth Sci., 952, 318-340.

Brunn J.H. 1956. Contribution a l' étude geologique du Pinde serpentrional et d' une partie de la Macedoine occidentale, Ann. Géol. Pays Hellénique, 7, 1-346.

$\underline{\text { XLVII, No } 2-560}$ 
Burg J.-P. 2012. Rhodope: From Mesozoic convergence to Cenozoic extension. Review of petrostructural data in the geochronological frame, in: Skourtsos, M. and Lister G., eds., The Geology of Greece: Journal of virtual Explorer, 42.

Burchfiel B.C., Nakov R. and Tzankov T. 2003. Evidence from the Mesta half-graben, SW Bulgaria, for the Late Eocene beginning of Aegean extension in the Central Balkan Peninsula, Tectonophysics, 375(1-4), 61-76.

Busby C.J. and Ingersoll R.V. 1995. Tectonics of sedimentary basins, Cambridge, Mass., U.S.A., Blackwell Science, Oxford, 579 pp.

Christodoulou G. 1958. Über das Alter einiger Formationen von Samothraki (in Greek with German summary), Bull. Geol. Soc. Greece, III/1, 40-45.

Christofides G., Pécskay Z., Eleftheriadis G., Soldatos T. and Koroneos A. 2004. The Tertiary Evros volcanic rocks (Thrace, Northeastern Greece): Petrology and K/Ar geochronology, Geologica Carpathica, 55(5), 397-409.

Doutsos T., Koukouvelas I., Zelilidis A. and Kontopoulos N. 1994. Intracontinental wedging and post-orogenic collapse in the Mesohellenic trough, Geolog. Rundschau, 83, 257-275.

Dragomanov L.K., Grigorov V., Ioncher A., Jelev A. and Darakchieva St. 1986. Lithological indications of the presence of Middle Eocene in the Eastern Rhodopes, Ann. Higher Inst. Mining Geol., 32, 37-41 (In Bulgarian with an English abstract).

Dumurdzanov N., Serafimovski T. and Burchfiel B.C. 2005. Cenozoic tectonics of Macedonia and its relation to the South Balkan extensional regime, Geosphere, 1(1), 1-22.

Goeruer N. and Okay A.J. 1996. A fore-arc origin for the Thrace basin, NW Turkey, Geol. Rundsch., 85, 662-668.

Ferrière J., Reynaud J.-Y., Pavlopoulos A., Bonneau M., Migiros G., Chanier F., Proust, J.-N. and Gardin S. 2004. Geologic evolution and geodynamic controls of the Tertiary intramontane piggyback Meso-Hellenic Basin, Greece, Bul.Soc. Géol. France, 175, 361-381.

Kilias A., Fasoulas C., Priniotakis M., Sfeikos A. and Frisch W. 1991a. Deformation and HP-LT metamorphic conditions at the tectonic window of Kranea (W Thessaly, Northern Greece), Z. dt geol. Ges., 142, 87-96.

Kilias A., Frisch W., Ratschbacher L. and Sfeikos A. 1991b. Structural evolution and metamorphism of blueschists, Ampelakia nappe, eastern Thessaly, Greece, Bull. Geol. Soc. Greece, 25, 81-89.

Kilias A. and Mountrakis D. 1998. Tertiary extension of the Rhodope massif associated with granite emplacement (Northern Greece), Acta Vulcanologica, 10(2), 331-337.

Kilias A., Falalakis G. and Mountrakis D. 1999. Cretaceous-Tertiary structures and kinematics of the Serbomacedonian metamorphic rocks and their relation to the exhumation of the Hellenic hinterland (Macedonia, Greece), Intern. J. Earth Sci., 88(3), 513-531.

Kilias A., Falalakis G., Gemitzi A. and Christaras V. 2006. Faulting and paleostress evolution in the Maronia-Petrota basin. Evidence of active faults, Bull. Tethys Geol. Soc., 1, 7-16.

Kilias A., Falalakis G., Sfeikos A., Papadimitriou E., Vamvaka A. and Gkarlaouni Ch. 2012. The Thrace basin in the Rhodope province of NE Greece - A tertiary supradetachment basin and its geodynamic implications, Tectonophysics, doi:10.1016/j.tecto.2012.05.008.

Kopp K.O. 1965. Geologie Thrakiens III : Das Tertiaer zwischen Rhodope und Evros, Ann. Géol. Pays Hellénique, 16, 315-362.

Lescuyer J.L., Bailly L., Cassard D., Lips A.L.W., Piantone P. and McAlister M. 2003. Sedimenthosted gold in south-eastern Europe: the epithermal deposit of Perama, Thrace, Greece, in: Eliopoulos D.G. et al., eds., Mineral exploration and sustainable development, 499-502, Millpress, Rotterdam.

Meinhold G. and BonDagher-Fadel M. 2010. Geochemistry and biostratigraphy of Eocene sediments from Samothraki island, NE Greece, N. Jb. Geol. Palaeont. Abh., 256(1), 17-38.

Marchev P., Kaiser-Rohrmeier M., Heinrich C., Ovtcharova M., von Quadt A. and Raicheva R. 2005. Hydrothermal ore deposits related to post-orogenic extensional magmatism and core complex formation: The Rhodope Massif of Bulgaria-Greece, Ore Geol. Rev., 27, 53-89. 
Most Th., Frisch W., Dunkl I., Balogh K., Boev B., Avgerinas A. and Kilias A. 2001. Geochronological and structural investigations of the northern Pelagonian crystalline zone Constraints from K/Ar and zircon and apatite fission track dating, Bull. Geol. Soc. Greece, 34, 91-95.

Kontopoulos N., Fokianou T., Zelilidis A., Alexiadis C. and Rigakis N. 1999. Hydrocarbon potential of the middle Eocene-middle Miocene Mesohellenic piggyback basin (central Greece): a case study, Marine and Petroleum Geology, 16, 811-824.

Maravelis A., Konstantopoulos P., Pantopoulos G. and Zelilidis A. 2007. North Aegean sedimentary basin evolution during the Late Eocene to Early Oligocene based on sedimentological studies on Lemnos island (NE Greece), Geol. Carpathica, 58, 455-464.

Papanikolaou D., Lekkas E., Mariolakos E., and Mirkou R., 1988. Contribution on the geodynamic evolution of the Mesohellenic trough, Bull. Geol. Soc. Greece, 20, 17-36.

Roussos N. 1994. Stratigraphic and paleogeographic evolution of the Paleogene Molassic basins of the Northern Aegean, Bull. Geol. Soc. Greece, 32, 275-294.

Schermer E.R. 1993. Geometry and kinematics of continental basement deformation during the Alpine orogeny, Mt. Olympos region, Greece, J. Struct. Geol., 15, 571-591.

Sfeikos A., Boehringer C., Frisch W., Kilias A., and Ratschbacher L. 1991. Kinematics of Pelagonian nappes in Kranea area, North Thessaly, Bull. Geol. Soc. Greece, 25, 101-105.

Tranos M., 2009. Faulting of Lemnos island: a mirror of the North Aegean Trough (Northern Greece), Tectonophysics, 467, 72-88.

Tranos M.D., Kilias A. and Mountrakis D., 1999. Geometry and kinematics of the Tertiary postmetamorphic Circum Rhodope Belt Thrust System (CRBTS), Northern Greece, Bull. Soc. Geol. Greece, 33, 5-16.

Vamvaka A., Kilias A., Mountrakis D. and Papaoikonomou J. 2006. Geometry and structural evolution of the Mesohellenic Trough (Greece), a new approach. In: Robertson A.H.F. and Mountrakis D. eds., Tectonic Development of the Eastern Mediterranean Region, Geological Society of London, Special Publications, 260, 521-538.

Vamvaka A., Spiegel C., Frisch W., Danišík M. and Kilias A. 2010. Fission track data from the Mesohellenic Trough and the Pelagonian zone in NW Greece: Cenozoic tectonics and exhumation of source areas, Intern. Geol. Review, 52(2-3), 223-248.

Wilson J. 1993. The anatomy of Krania basin, northwest Greece, Bull. Soc. Geol. Greece, 28(1), 361-368.

Zelilidis A., Piper D.J.W. and Kontopoulos N. 2002. Sedimentation and basin evolution of the Oligocene-Miocene Mesohellenic basin, Greece, $A A P B, 86,161-182$.

Zygogiannis N. and Müller C. 1982. Nannoplankton-Biostratigraphie der tertiären Mesohellenischen Molasse (Nordwest-Griechenland), Z. dt geol. Gesel., 133, 445-455. 